\title{
Teaching Democracy: Tools and Methods in the Secondary Education
}

\author{
Theodore Chadjipadelis ${ }^{1}$, Marina Sotiroglou ${ }^{2} \&$ Antonis Papaoikonomou ${ }^{3}$
}

\section{ARTICLE INFO}

Article History:

Received 01.12.2019

Received in revised form

25.06.2020

Accepted

Available online 01.10 .2020

\begin{abstract}
Political and Social scientists, since the end of the 20th century, have been concerned about youth's "withdrawal" from participating in public life. This paper addresses the issue of teaching Civic Education and presents new didactic and interactive tools that can be used in the educational process. Introducing the meaning of Democracy to students takes place in compulsory education but during Secondary Education is taught extensively with the aim of creating responsible and interactive citizens. Therefore, students are exercised in democratic procedures during courses, interactive learning and by electing students' board into school premises in order to motivate political participation and political understanding. However, an individual is not considered as a citizen only on the election day. To this end, thematic workshops were designed and implemented by using the principle of deliberation in schools in the area of Thessaloniki (Greece), in the context of the course "Contemporary World, Citizen and Democracy" in Secondary Education. The workshops focused on the familiarization with the Greek and European Parliament functions into the school communities by interactive and experiential learning. At the end of this approach, a survey was conducted to students concerning their opinion about deliberation and electoral procedures. In that terms, we aim to develop a structured and interactive Civic Education curriculum that will help shape active and responsible citizens. Our teaching practice is based on mathematical skills and statistical concepts to cultivate further the concepts of democracy and representation.
\end{abstract}

(C) IJERE. All rights reserved

Keywords:

Democracy, civic education, secondary education, deliberation.

\section{INTRODUCTION}

Political and Social scientists, since the end of the 20th century have been concerned about youth's "withdrawal" from participating in public life (due to limited interest and poor participation in electoral policies), their democratic responsiveness (Jacobs and Shapiro, 2000) and their rejection of traditional means of civic and political collective actions. This issue has been discussed worldwide and many interventions had been made in this perspective. Thereby, it is vital to design a pedagogy of Political Science that aims to high level of civic and political engagement in schools. This paper addresses the issue of teaching Democracy in schools, specifies the used teaching tools and introduces new methods that could be implemented in the educational process. The aim is to cultivate the fundamental principles of Democracy and analyze the competences of the basic institutions. Introducing the meaning of Democracy to students takes place in compulsory education, but during Secondary Education is taught extensively in order to create responsible and interactive citizens. Besides lecturing, the teaching tools that can be used are additional activities focused on the familiarization with the Parliament functions into the school communities by interactive and experiential learning. In that terms, we designed workshops which "integrate" and "implement" the democratic principles, the representative system, the electorate and deliberation.

The concept of representation, the role of the representative (i.e. study of ballot forms, party-lists, ranked ballots, first-past-the-post systems), the electoral system (i.e. the proportional system, first-past-thepost voting, two-round system, ranked voting or mixed systems- in the case of Greece) and the electorate's voting criteria are the most important issues for an effective democratic system (Chadjipadelis \& Sotiroglou, 2018). An individual is not considered as a citizen only on the election day. In the book "Deliberation in the classroom: Fostering Critical Thinking, Community, and Citizenship in Schools" teachers stated that the educational system does not provide the adequate knowledge (Molnar-Main, 2017) so as students to become active citizens (Chadjipadelis \& Sotiroglou, 2017). The goal is to prepare students for real life and citizenship. The purpose of our approach is to relate the aforementioned issues to the school / student community, which is an introductory in state organization and governance. Students, like citizens, elect representatives for their student councils. Thus, appointing delegates to the fifteen-member students' councils, acts as a simulation of the electoral process and the democratic principle of representation. This paper proposes new teaching methods to encourage and motivate students to become active citizens with the skills of responsibility, social solidarity and collective action. The secondary aim is to promote statistical thinking and statistics in order to 
cultivate further the concepts of democracy and representation. In that terms, we aim to develop a structured and interactive Civic Education curriculum that will help shape active and responsible citizens.

\section{Teaching tools}

This approach proposes that the school / student community can develop mathematical and statistical thinking throughout the concept of Democracy and theme workshops. Students learn how to use the results of elections, calculate probabilities and take political decisions based on real facts. Our didactic approach was designed by using the following teaching tools: thematic workshops, deliberation, moderating, teambased learning (TBL), project activity, posters, choice-based conjoint questionnaire and evaluation of the results. Deliberation can be identified as a free dialogue based on equality of all participants debate and offers opportunities to express opinions. Thus, deliberation seems to be an increasingly common way wherein citizens participate in politics therefore students could be exercised in deliberation methods into their school. Surveys (Latimer and Hempson, 2012) prove that a deliberative dialogue is more likely to increase civic knowledge and to increase levels of anticipated participation in electoral policies.

Workshops introduce students to specified themes within additional activities which will integrate students into society. Workshops can build students' confidence by discussing important things with minimum teachers' supervision but in the presence of a friendly and young moderator. Workshops develop students' teamwork skills and self-confidence. The workshops' themes were about students' community, students' council elections (school assemble), the European elections and political knowledge. Also, students, through interactive learning and TBL, can be familiarized with democratic processes and active participation in their everyday life. The aim of TBL is to familiarize students with electoral laws, electoral and party system. Moreover, TBL seems to be more efficient teaching method, than lecturing, which cultivates interactive students and motivates them to explore the concepts of representation. It is proposed that the teaching materials and teaching practices can be enriched with additional activities to familiarize students with parliamentary functions through (and) experiential actions. Team-based learning method, project assignments and workshops can be combined with additional activities that focus on simulating representative bodies into the school communities by interactive and experiential learning. Project assigning offers the opportunity to dedicate significant amount of class-time over students in order to plan and organize their work. Students will be served as citizens and comprehend how to develop critical thinking without teachers' intervention. Moreover, students can interact with each other and broaden their horizon with practices like self and group-direct learning, shared decision-making and group project-based work.

The theme workshops were held under the supervision of the Department of Political Sciences' students of the Aristotle University of Thessaloniki (AUTH), Greece. Undergraduate students had the role of the moderator as neutral participants in the debate. Students/Moderators' goal was to organize the debate so as the participants could fully develop their argument about the discussed theme, held participants to time limits and tried to keep them from straying off the topic in the debate. In detail, moderators could freely implement their teaching approach by using posters, project activities or/and focus groups. First, moderators introduced the participants (Secondary-schools' students) to the principle of the deliberation and afterwards organized the debate based on the workshops' themes. The workshops focused on the familiarization with the Greek and European Parliament functions into the school communities by interactive and experiential learning. During the workshops, the participants answered to a conjoint questionnaire and at the end of this approach, another survey was conducted concerning students' opinion about deliberation and electoral procedures.

\section{Political participation and education}

The fundamental principle of political participation and active citizenship in a democracy have been promoted in educational policies both internationally and nationally. These policies' aim is to provide social skills and cultivate Participatory Democracy to young people. Active participation is considered a fundamental principle of the democratic systems, for politicians and political decision-makers (Council of Europe, 2010b). Strategy for participatory and comprehensive activities, as presented by the EU, the Council of Europe and other national education organizations, could be an attempt to combine practical application and civic education for effective public engagement (Birzea et al., 2005. Gollob, Krapf \& Weidinger, 2010a, 2010b). A democracy needs active citizens and research-based policies to ensure that political participation is 
effectively taught to students. Students as citizens will use the acquired skills, will be active and will contribute to the perpetuation of democracy (Council of Europe, 2002. Schulz et al., 2010a, 2010b). At the same time, policy updating guarantees better implementation of educational programs and continuous improvement. In these educational policies and related teaching materials as well as in related research on political education, the basic ideas of democracy are given but in fact they need to be consolidated. Democracy is often referred with emphasis as a good, fair and harmonious feature of European societies, but it should be supported by educating citizens who will actively participate in a democracy (Eurydice, 2005. Hoskins, 2006). Representation is the basic principle in modern democracies and every collective action is associated with forms of representation. For instance, the election of representatives is usually the primary method of introducing students to participation and decision-making policy.

In addition, debating and deliberating are characteristics of democracies, the institutions' active participation policies and the practices of participation itself. The above seem to be taken for granted at European level of political education and the related research that is based on an expected common understanding of active political behavior, democracy and participation (Hoskins \& Mascherini, 2009. Torney-Purta et al., 2001). Differentiations regarding cultural differences, gender or main political and social beliefs considered superfluous. Educational policies at international level are based on a unified concept of education policy which has good and bad practices nowadays. But despite theoretical, political, and educational differentiation and confrontation, unifying concepts such as democracy, active political behavior and participation as common model of European policy remains a challenge. Critical analysis of participation policies and practices prove that these problems are significant and cannot be ignored. Political participation can be considered as participation in public debates, and disagreements over the recognition of diversity (Held, 2006. Norris, 2011). That is why civic education risks of achieving the opposite effect; depoliticization, if it remains a mere pedagogical practice without the conditions for political participation and intervention. For these reasons, this paper presents a structured and interactive "Civic Education" curriculum that will help shape active and responsible citizens. In schools' communities we can develop students' initiative and socialization skills. Political socialization is seen as a function, carried out by the political system, to convey politically relevant information, attitudes and values. Scholars can investigate the social structures, the processes and the factors that applied to maintain the party system (Sears \& Valentino, 1997. Sherrod, Flanagan \& Youniss, 2002).

The development of the field was based on the dynamic perception of the individual during his/her socialization, not only throughout understanding the existing political system but also contributing to political and social innovation. The dynamic nature of citizens' socialization based on the view that politics founded on specific patterns of thinking can be changed and reversed (Fahmy, 2006. Feldmann, 2007). The main aspect of socialization theory is the view that the consolidation of the political system is required, but that it presupposes a process of critical reflection through the education of young people, understanding political phenomena while simultaneously controlling their effects on daily life (Furlong \& Cartmel, 2006). The term of Civic Education is introduced to the educational process within the school premises and aims to political socialization. It is the individual's assimilation to state's values and social behavior. Typical examples are the participation of individuals in electoral processes and decision-making at local and national level. This process requires that students are familiar with the electoral and political system with the help of mathematics. Therefore, students are exercised in everyday examples on how to implement mathematics on the discipline of democracy and therefore motivated to learn mathematical and statistical concepts in order to be able to understand governmental policies and how to make personal decisions as responsible citizens.

\section{METHODOLOGY}

\section{Survey sample and procedure}

The survey conducted within the framework of the "Political Education Teaching" core course of the Department of Political Sciences, AUTH, Greece. Aiming to develop new teaching tools, we provided the appropriate guidance and teaching tools to undergraduate students in order to design, organize, and develop teaching materials with modern teaching methods. The 24 undergraduate students served as moderators, used their own material and presented it during a one-hour pilot teaching course in High Schools. The material was based on the students' community features, the student's elections, the European 
Union and the European elections. The thematic workshops were designed and organized by using the principle of deliberation and team-based learning in schools during the academic year 2018-19, as part of the core course "Modern World, Citizen and Democracy" in the $2^{\text {nd }}$ grade of High School. Moreover, students/moderators provided a one-hour tutorial to the participants based on the principle of deliberation while previously informing them about the process and educational purposes of deliberation. This intervention was implemented in 14 High Schools in the area of Thessaloniki (Greece) and 500 questionnaires were collected from High school students (participants). In every workshop, the participants completed two different questionnaires at the beginning and at the end of the teaching approach. During the workshops, data were collected by using a choice-based conjoint questionnaire and analyzed with Conjoint Analysis Method (Orme, 2010). And at the end, a second questionnaire was provided to the participants in order to state their attitudes, opinions and evaluation of the deliberation approach.

\section{Study instrument}

The first survey investigates the attitudes of students towards the European Union, the degree of political knowledge, the political motivation, the election vote intention, the interest in politics, the sources of information, values and perceptions of democracy and where they place themselves on the Left-Right political spectrum (0-10). Moreover, by using different representations of the Republic, the participants were asked to select 3 images (out of 12) that they thought relevant to the Republic.

During the workshops, the participants have the chance to express their opinion and evaluation of the deliberation throughout the scenario questionnaire. The participants stated the level of interest on the idea of thematic workshops and evaluated the didactic approach. Moreover, the participants evaluated 8 different scenarios that were shaped via different sets of characteristics / factors. The response scale is from 1 to 8 . In our case, the profile set to "1" represents this combination of characteristics that will work best for the school community and gradually reach the "8" that represents profile options that the respondent thinks will be less effective. The scenarios were based on the School Assembly, Nominating students' council and European Parliament election 2019 (the fist-time voters in Greece).

Regarding, the School assembly, every school year in Greece, during September, student's elections are held wherein school council's representatives are elected. The election of the fifteen members for the entire School assembly's representatives is a simulation of the electoral process and the democratic principle of political representation and participation. The school assembly of each student community includes all students of each class in every school premises. It is the supreme body of each student community. Through dialogue and participation students are exercised to the democratic process. Consequently, students' communities are suitable to cultivate initiative in schools. At this meeting, the students discuss and decide on the problems and issues that concern them (LAG2 / 336/1991). The question is how the school assembly should work according to the students' opinion. In this scenario we asked the students to classify the eight profiles based on five levels of factors: the board election system (candidates or parties), representation (one student from each department or all), problem solving (active participation or counseling), election of the 15member board (re-quired or not) and the coordination of the schools at the municipal level (yes or no).

All members of the student community have the right to submit their candidacy or be nominated to the students' council. Council elections should be held, after a candidates' debate on student and school problems. The question concerns the criteria by which students vote for their representatives. The scenario questionnaire was based on five levels of factors: representative characteristics (assertive-consensual), priority (school or class), student / candidate performance (good student or not good), social skills (communicative or not) the popularity factor (popular or not).

Also, on 26 May 2019, elections were held for the election of representatives of the European Parliament. The questions in this case was about the voting criteria of the new voters. Factor levels were; party (ideological principles and worldview), individuals (candidates and political staff), important issues (programme address and proposals) and cooperation (meaning the need or not of parties willing for).

\section{Data analysis}

The method of Conjoint Analysis was applied to analyze the data (Halme \& Kallio, 2011) in the IBM SPSS Statistics (25). Conjoint Analysis is an effective method for studies which focus on the formation of 
behavior via the scenario questionnaire. Students at the end of each workshop were asked to prioritize the given profiles (scenarios). Conjoint Analysis allows researchers to explore and map individuals' choices as a result of decisions between multiple and different characteristics / factors / profiles. These characteristics / factors are pre-defined by the researchers. Each time we explore a concept or situation, we determine the characteristics or factors that respond to the initial research goals and shape the profiles. We evaluated the utility of each factor and we analyzed the components of the total preference in order to estimate the relative importance for each characteristic or factor. So, the relative importance of each characteristic / factor shows its contribution to the "total preference" of the students. Based on the above, the orthogonal experimental design was used in order to estimate the main effects of the levels and the utility of each factor.

\section{RESULTS}

\section{School Assembly}

The results show that students consider necessary to elect the 15-member board in order to actively participate in matters related to their school unit. They vote candidates (individuals) and choose that each class should be represented separately. They also want to coordinate schools at a municipal level so that they can promote their problems / needs / issues to local authorities. The factor with the highest relative importance is the "15-member election" (25.3\%) and the "election system" $(22.2 \%)$ comes second in ranking.

\section{Nominating students' council}

Students prefer their board representatives to be students with good performance in class, and popular with communication skills. They vote students who have high interest in their school and take initiatives. The factor with the highest relative importance is the "priority" with $31.1 \%$ and "communication skills" $(25.8 \%)$ in ranking.

\section{European Parliament election 2019, the fist-time voters in Greece}

The analysis shows that "party" is the most important factor, followed by "cooperation", "important matters" and "persons". Moreover, the participants stated that they take into consideration the ideological principles of the parties, their position on cooperation, their pre-election positions and eventually the candidates and political staff. The factor with the highest relative importance is party $(30.6 \%)$ and cooperation $(28.0 \%)$.

\section{Principle of deliberation}

At the end of the workshops, the participants assessed the principle of deliberation and the process followed. $78.0 \%$ of the students stated that the consultation process was useful and $72.0 \%$ said they were sufficiently informed about the issue under consideration. Upon completion of the workshop, $18.0 \%$ stated that their initial view of the subject had not improved at all, while $80.0 \%$ of students said that their initial view had improved ("very" by $6.0 \%$, "quite" by $30.0 \%$ and "little" with $44.0 \%$ ).

\section{Elections and political knowledge}

Students trust the European Union (38.0\%), believe that there are no common European policies $(62.0 \%)$, believe that the European Parliament should have more powers $(48.0 \%)$ and that European citizens should be more involved in decision making $(86.0 \%)$. They feel that they are not informed about institutions and policies (55.0\%) and think that our country's opinion (43.5\%) and their opinion (53.5\%) are not taken under consideration in the EU.

Regarding their intention to vote, $72.8 \%$ intended to vote, $10.4 \%$ said that would cast an invalid / white vote, $13.3 \%$ would abstain and $3.5 \%$ did not respond. Of the total number of students, $1.0 \%$ has been excluded because they did not have the right to vote at that time. $40.0 \%$ of students stated that they are interested ("very" and "quite") in politics, $46.5 \%$ "little" and $12.5 \%$ "not at all".

Of the total number of students who said they would vote $(16.0 \%)$, there is no justification for their decision. Of the rest (multiple choice), $50.0 \%$ would vote due to sense of responsibility, $43.2 \%$ said for the experience, $26.5 \%$ referred to citizenship, $28.8 \%$ referred to collective responsibility and $18.7 \%$ would advocate for the future. Those who said that they would cast an invalid /white vote or would abstain, 
justified their decision by $31.8 \%$. Of the rest, $38.8 \%$ said they had no opinion, $31.3 \%$ lacked information and $27.5 \%$ lacked confidence in parties and politicians.

Regarding the forms the political motivation, $19.0 \%$ prefers forms of collective action, $20.0 \%$ choose to operate via social media, $21.0 \%$ opt for individual deliberation and $40.0 \%$ do not take any action. Only $5.0 \%$ of them said they are not interested in politics. The other students who report their two main sources of information: the first in the list is the Media (Television, Radio: $53.0 \%$ ) and the second is family (43.5\%). One in three $(34.0 \%)$ is informed by social media and one in four by the Internet. $14.5 \%$ gets information from social environment and $5.0 \%$ from newspapers and magazines.

The Left-Right political spectrum classifies the participants' political position from the left to the right. Self-placement on the Left-Right spectrum shows a normal distribution curve at the center, implying that this is where majority opinion lies (mean 4.77).

Diagram 1: Left-Right political spectrum

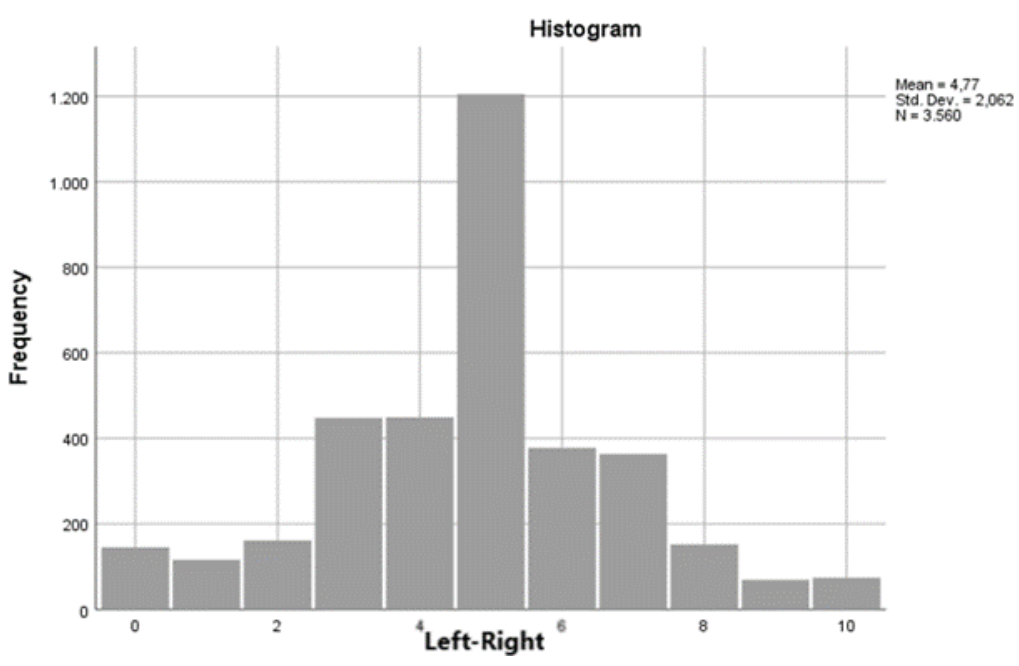

The first image depicts a symbolic representation of the representative Republic (46.0\%). More than $30.0 \%$ of the images depict "Ancient Greece" (38.5\%), "Protest" (37.0\%), "Direct Participation" (36.0\%) and "Direct Democracy" (31.0\%).

Picture 1: Representative Republic

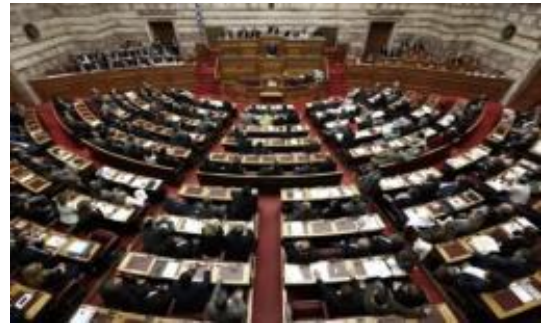

Picture 2: Ancient Greece
Picture 4: Direct Participation

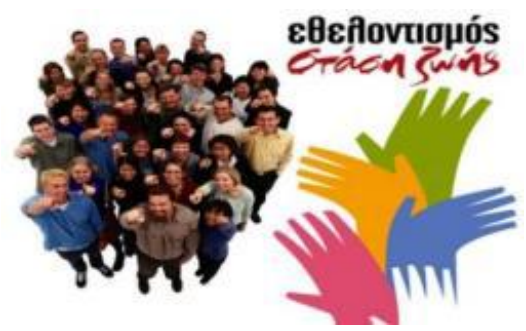

Picture 5: Direct Democracy 

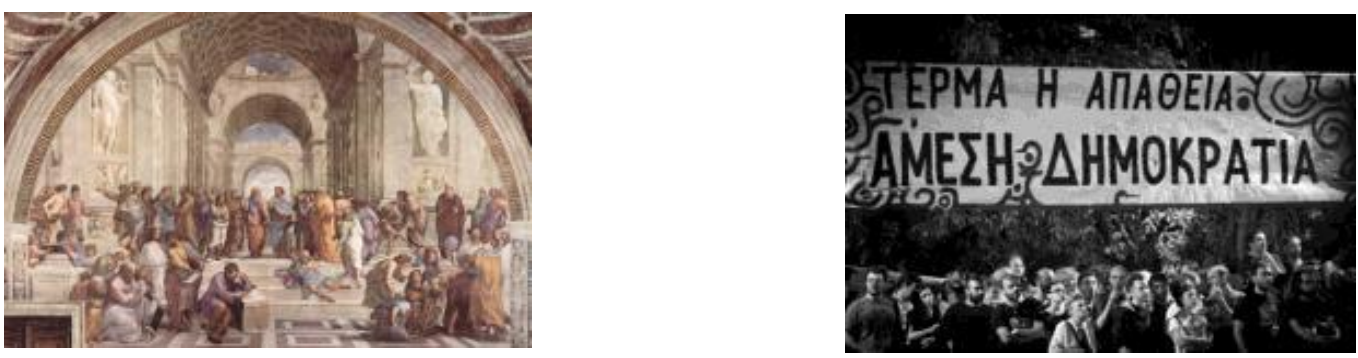

Picture 3: Protest

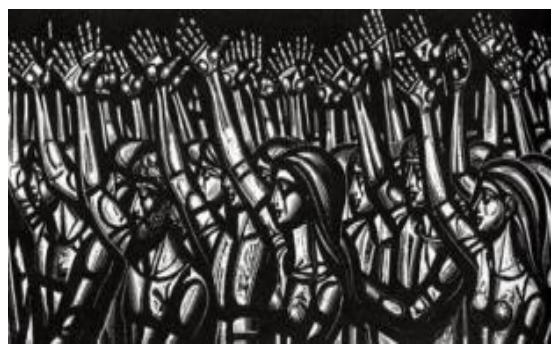

\section{DISCUSSION AND SUGGESTIONS}

To summarize, we designed and organized workshops that cultivate the democratic principles. Modern and interactive teaching methods (Biesta and Lawy 2006, Biesta 2011) should be developed in order to cultivate democratic principles and familiarize students with the institutions function in state, integrate and comprehend those principles, the electorate, the Parliament, the government and citizenship (Nicoll et al. 2013). Moreover, students can interact with each other and broaden their horizon with practices like self and group-direct learning, shared decision-making and group project-based work.

This didactic approach was designed by using; thematic workshops, deliberation, moderating, teambased learning (TBL), project activity, posters, choice-based conjoint questionnaire and evaluation of the results. The implemented thematic workshops organized by using the principle of deliberation seemed to be fruitful. Through this approach, the aim was to encourage students to become active citizens with the skills of responsibility, social solidarity and collective action. In addition, we tried to promote statistical thinking and to cultivate further the concepts of democracy and representation. In that terms, we developed this Civic Education curriculum that will help shape active and responsible citizens.

Utilizing workshops can provide efficient atmosphere in class to stimulate public discourse about representation issues and the role of representatives. This method can also provide tools for designing the appropriate framework for integrating students to electoral procedures and towards deliberative dialogue to increase civic knowledge and to increase levels of participation in electoral policies. Workshops are highly recommended in order to formulate and establish democratic principles, the representative system, "good" citizenship behavior (Reichert 2016), and generally engaged students into civic society. During our teaching initiative, students/participants seemed to be intrigued and interested in the idea of thematic workshops.

Nowadays, we are witnessing the beginning of an experiment with new and innovative forms of micro-democracy of "governing with the people", and we are more and more open to different forms of civic participation (Schmidt 2006, Elster 1998, Manin 2005, Bobbio). Deliberation can be identified as a free dialogue based on equality of all participants argument context and offers changes to initially held opinions (Elster 1998, Manin 2005). Thus, deliberation seems to be an increasingly common way wherein citizens participate in politics therefore students could be exercised in deliberation methods into their school board. Surveys (Latimer and Hempson 2012) prove that a deliberative dialogue is more likely to increase civic knowledge and to increase levels of anticipated participation in electoral policies. 
Further, it could be useful to establish the interaction with school communities in other European countries. So, students of High Schools could communicate with students in other countries by exchanging opinions and noting similarities and differences between their communities. Students would identify similarities and differences in the characteristics of democratic process, education, culture, politics and teaching methods that are used and comprehend the concept of Democracy in comparison with other students. Therefore, it could be used an exchanging program for students (e.g. Erasmus+) in order to live and experience the everyday life in other school communities and observe other school councils.

Finally, this teaching approach is an ongoing procedure. The interest of the undergraduate students of the Department of Political Sciences, in teaching Civic Education and students of Secondary Education willingness to participate in our initiative, sets the pace for us to organize new workshops.

\section{REFERENCES}

Biesta, G. (2011). Learning democracy in school and society, education, lifelong learning and the politics of citizenship. University of Stirling, UK, Sense Publishers.

Biesta, G., \& Lawy, R. (2006). From teaching citizenship to learning democracy: overcoming individualism in research, policy and practice. Cambridge Journal of Education, 36(1): 63-79. doi: 10.1080/03057640500490981

Bîrzea, C., Cecchini, M., Harrison, C., Krek, J., \& Spajić-Vrkaš, V., (2005). Tool for quality assurance of education for democratic citizenship in schools. Paris: UNESCO, Council of Europe and CEPS. Retrieved from

Chadjipadelis T. \& Sotiroglou M. (2017). Teaching mathematics and electoral systems in political science, AUTH Department. In J. Morskan \& A. Rogerson [WTM Munster] (Ed.) Challenges in Mathematics Education for the Next Decade (3): 46-5.

Chadjipadelis, T. \& Sotiroglou, M. (2018). Mathematics and statistics in democracy. A cross-curricular approach. In proceedings of 10th International Mathematics Week 2018, Greek Mathematics Association, Quarter of Central Macedonia, 25-29 April, Thessaloniki (In Greek).

Council of Europe (2010). Recommendation 1849 (2008) for the promotion of a culture of democracy and human rights through teacher education. Strasbourg: Council of Europe.

Council of Europe, ed. (2002). Stocktaking research on policies for education for democratic citizenship and management of diversity in Southeast Europe. Regional Analysis and Intervention Proposals. Strasbourg: Council of Europe.

Elster, J. (1998). Deliberative democracy. Cambridge University Press, Cambridge, UK.

Eurydice. (2005). Citizenship education at school in Europe. Brussels: European Commission.

Fahmy, E. (2006), Young citizens: young people's involvement in politics and decision making. Bristol: Ashgate.

Feldmann, G. (2007).Classroom civility is another of our instructor responsibilities, College Teaching, 49(4): 137-140.

Furlong, H. \& Cartmel, A. (2006). Young people and social change. McGraw-Hill Education (UK).

Halme, M. and Kallio, M. (2011). Estimation methods for choice-based conjoint analysis of consumer preferences. European Journal of Operational Research, 214(1): 160-167.

Held, D. (2006). Models of Democracy. Third Edition. Cambridge: Polity.

Hoskins, B. \& Mascherini, M. (2009). Measuring active citizenship through the development of a composite indicator. Social Indicators Research, 90(3): 459-88.

Hoskins, B. (2006). Working towards indicators for active citizenship. Report from the Active Citizenship for Democracy Conference. Retrieved from http://crell.jrc.ec.europa.eu/download/Conferences/conference\%20report\%20final3.pdf.

Jacobs, L. R. \& Shapiro R. Y. (2000). Politicians don't pander: Political manipulation and the loss of democratic responsiveness. Chicago: Univ. of Chicago. 
Latimer C. \& Hempson K. M. (2012). Using deliberation in the classroom: A teaching pedagogy to enhance student knowledge, opinion formation, and civic engagement. Journal of Political Science Education, 8(4): 372-388.

Latimer, C., \& Hempson, K. M. (2012). Using deliberation in the classroom: A teaching pedagogy to enhance student knowledge, opinion formation, and civic engagement. Journal of Political Science Education, 8(4): 372-388.

Manin, B. (2005). Democratic deliberation: Why we should focus on debate rather than discussion. Program in Ethics and Public Affairs Seminar. Princeton University.

Molnar-Main, S. (2017). Deliberation in the classroom: Fostering Critical Thinking, Community, and Citizenship in Schools. Dayton: Katerring Foundation.

Nicoll, K., Fejes, A., Olson, M., Dahlstedt, M. and Biesta, G. (2013). Opening discourses of citizenship education: A theorization with Foucault. Journal of Education Policy, 28(6): 828-846. doi: 10.1080/02680939.2013.823519.

Orme, B. (2010). Getting started with conjoint analysis. 2nd ed. Madison, WI: Re-search Publishers, LLC.

Reichert, F. (2016). Who is the engaged citizen? Correlates of secondary school students' concepts of good citizenship. Educational Research and Evaluation, 22,(5): 305-332. doi: 10.1080/13803611.2016.1245148.

Schmidt, A. Vivien (2006). Democracy in Europe. The EU and National Politics. Oxford University Press, Oxford.

Sears, D. \& Valentino, N. (1997). Politics matters: Political events as catalysts for preadult socialization. American Political Science Review, 91(1): 45-65.

Sherrod, L. R., Flanagan, C., \& Youniss, J. (2002). Dimensions of citizenship and opportunities for youth development: The what, why, when, where, and who of citizenship development. Applied Developmental Science, 6(4): 264-272.

Torney-Purta, J, Lehmann, R., Oswald, H., \& Schulz, W. (2001). Citizenship and education in twenty-eight countries: Civic knowledge and engagement at age fourteen. Amsterdam: IEA. 